\title{
The Early Childhood Learning Models Based on the Local Wisdom in Madrasah Qudsiyyah Kudus
}

\author{
Khasan Ubaidillah ${ }^{1}$ \\ IAIN Surakarta, Indonesia \\ Correspondence: addamawy94@gmail.com
}

\begin{abstract}
This research is motivated by the declining phenomenon of the Kudus society's understanding on local wisdom which becomes the character and philosophy of their life, that is Gusjigang which contains the characters of Bagus Lakune (good behavior), Iso Ngaji (good at reciting Qur'an and 'Kitab Kuning'), and Iso Dagang (good at trading/merchant). Thus it is necessary a means that can be a solution to reaffirm the understanding values of Kudus society. For the author, the agenda of strengthening the local wisdom values will be more effectives when carried out through education and integrative learning that unify text and context of life. Due to this means will facilitate the achievement of local wisdom understanding through the material and the interaction that occurs between individuals in learning. In order to get more influential impact, then it presumably should begin at the early age, as implemented in Madrasah Qudsiyyah Kudus. Since in the golden age, the absorbing power of the child's brain on the received knowledge is much greater than when they had grown and mature, therefore by implementing Gusjigang values (local wisdom of Kudus) in the early age of children will leave a positive behavior as the foundation for their future. This research aims to take a picture in detail about the early childhood learning in Madrasah Qudsiyyah comprehensively, thus the expectation is to find an ideal learning model related to the local wisdom-based learning for the early age children.
\end{abstract}

Keywords: local wisdom; Gusjigang; early childhood learning 


\section{INTRODUCTION}

Early childhood learning design in principle covers all matters related to interaction process between children, teachers, or parents in an environment to achieve the task of development, thus it provides a real experience for the children in order that they are motivated and acquire meaningful learning experiences.

The early childhood learning is an interesting and entertaining learning which stimulate creativity and imagination of children - oriented to the basic aspects of children development. It is perhaps a general idea of how to design a learning model that is friendly for the children and their growth.

Therefore, in preparing a lesson for the early age children, an institution have to comprehend and arrange correctly the basic foundations of the children development, in order that the development of children during the learning process can lead to positive foundation, thus they will grow into well behaved individuals that have good characters for themselves, their family, and society. To accomplish this comprehending, Madrasah Qudsiyyah Preschool "shifir class" as one of the Educational Institution for the early childhood that has religious characteristics also formulate the best foundation in designing the learning models for the students.

As one of the Educational Institution for the early childhood in Kudus, especially in the area of Cultural Heritage of 'Kudus Menara' Minaret, Madrasah Qudsiyyah is different from other kindergartens, that is in the practice of teaching, it only accepts and educates boy students. Regarding why Madrasah Qudsiyyah only accepts and educates boy students, the researcher got the answer from the book entitled El-Wijhah Wolu Windu Qudsiyyah Edition. The book explains that from the beginning the manager of Madrasah Qudsiyyah only accepts boy students, thus Madrasah Qudsiyyah is known as Boys' School, which is different from the Girls' School 'Madrasah Banat' (incidentally in adjacent locations) that accepts only girl students. This is done by the management, because it is the practice of hereditary performed since Qudsiyyah was first set up by KHR Asnawi in 1919 AD. In addition to this, there is another factor, based on "Salaf" Frame which is believed by Qudsiyyah, joining boy and girl students in a classroom is not good. So on that basis, until now the manager of Madrasah Qudsiyyah including "Shifir" Qudsiyyah only accept and educate the boy students in the learning process, although sometimes there are some advices to also accept girl students. 
In the context of the student's characters development, Madrasah Quddsiyyah always try to become a trend setter of an educational institution that applies the life philosophy of Kudus society as the basic foundation for the development of their students' characters, thus the Madrasah Qudsiyyah's students could be the successor and protector of the Kudus society's cultures. In the National framework, the design of character education which based on the local wisdom of a region will be the reinforcement of the character education program that has been endorsed by the government.

Presumably there are many people who have not known yet about the life philosophy of the Kudus society as the author mentioned above, because during these days Kudus is better known as Cigarette 'Kretek' City or the town of stick porridge 'jenang' maker. Whereas in the more substantial living space, the Kudus society has a life philosophy that has to be followed in order to be the real Kudus people. The life philosophy of the Kudus society is Gusjigang. These are Gus for Bagus Lakune (good behavior), Ji for Iso Ngaji (good at reciting Qur'an and 'Kitab Kuning'), and Gang for Iso Dagang (good at trading).

Gusjigang in common languange is often termed as Merchant Santri (Student), that is a well-mannered Santri, an intellectual, and also a merchant. The life philosophy certainly does not just exist then being memorialized, however this ideal life value have to be preserved and implemented by the Kudus society in their daily life.

In this research study, the author offers 'learning' as a way to preserve the life philosophy, or in this article becomes the local wisdom value of the Kudus society. The author wants to show an endeavor that is undertaken by the manager of Madrasah Qudsiyyah, who was from the first time seriously integrated the wisdom of Gusjigang as the foundation for the character development of the early age children who studied in the educational institution that is often referred to as "Menoro School". The seriousness normatively can be viewed from the vision of the Institution, namely: "Firm in the Faith, High in the Science and Noble in the Character", thus there are the elements of faith, science and morality, which all of them could be the basic spirit for the people to have strong work ethics like a merchant.

\section{Integration of local wisdom in the early childhood learning}

The early childhood learning program held at Madrasah Qudsiyyah contains activity that is being a manifestation of the various agenda in the curriculum. 
Indicators of this learning activity are developed in accordance with the value of Gusjigang local wisdom consisting of three values of wisdom, with the development design as follows.

\section{Aspect of Commendable Moral (Nilai Bagus Lakune)}

The development of moral aspect or lead to commendable behavior is the basic spirit of the early childhood character development. Since one of the parameter of a person's character can be seen from his behavior. The implementation of this moral aspect in Madrasah Qudsiyyah translated in accordance with the scope of early childhood development, especially aspect of language.

It is important to be known that actually the language development in $R A$ Qudsiyyah is one of the important aspect of constructing the early childhood character with the value of good behavior "Bagus Lakune", because the language is an aspect that can be assessed. A child who has 'Bagus Lakune' value is the one who is able to communicate courteously.

Usually, the scope of language development in Madrasah Qudsiyyah essentially teaches the children to perform better verbal communication. If the early childhood accustomed to vent his emotions in his own way that is difficult to be understood, for example crying when requests for something, hence in this scope, he is taught to express his requests verbally.

The children are expected to express their requests with the proper language, whether in the form of opinions, questions or answers. Thus, they are able to socialize with the society. By means of optimal socialization, they also have opportunity to expand their horizon through observation.

It is the reason why language skill is also significant as its supporting education, especially to obtain materials in the school. In many instances, teacher conveys the materials by giving speech consisting of some advices. As what M. Aftoni, S.P.d.I (the principal) does during the speech at the flag ceremony. Providing materials like this will be well received when the children have a good grasp of the teacher's description. The improvement of the language skill in the learning process appears at the indicators that have been developed within the language scope.

The scope of language development is divided into three parts, those are; receiving language, expressing language, and literacy. In the scope of receiving language development, the children are given more stimuli by the teacher, and then they respond by imitating or doing relevant things. This is different from the scope of 
expressing language that shows the children who are being active. While literacy, is more as language enrichment.

For example, in the first indicator, the stimuli that can be given are listening and retelling simple stories. The teacher as facilitator plays an important role in this section. Furthermore, the scope of expressing language development, the children are more actives in performing their ability, for instance, there are an indicator of expressing feelings using adjectives, telling about provided images or drawing their own and singing the children's song.

The language enrichment within the scope of literacy for instance by connecting images or objects with the words, constructing meaningful scribbled, and writing the alphabets. At this stage, the teacher's role is more as observer and assessor who provide an assessment of the children development level and creativity to develop.

\section{Aspect of Intellectual and Religious (Nilai Pinter Ngaji)}

The development of intellectual and religious aspects of learning in Madrasah Qudsiyyah interpreted into two scopes of children development, those are:

\section{a. Cognitive}

The scope of cognitive development in Madrasah Qudsiyyah is developed into indicators of activities that teach the children to be able to obtain, manage, and understand various kinds of information conveyed to them. The cognitive development of $R A$ Qudsiyyah's students is used as a development media of three values of Pinter Ngaji, as basically in this cognitive space mention a lot about some basic knowledge that strongly support the children's intellectual.

As far as the author observation, the scope of the cognitive development is dominated by the activities of concept identification. The concept identification of the knowledge aspect usually is used to give comprehension to the children about the kindness, the way to write and spell as a provision for them to recognize the book that is learned in Madrasah Qudsiyyah Kudus.

In addition, the concept identification of shapes, colors, sizes, and patterns uses more objects that can be used to play. While the concept identification of numbers, symbols of numbers and letters are more abstract by using the writing media of numbers and letters symbols. In this aspect the children are taught to think abstractedly and mathematically. But, the symbols of numbers are not operated by itself, it is using real object media as the visual aid, such as blocks and puzzles. In this section, to give a balance to the early childhood, they are not only taught about 


\section{THE EARLY CHILDHOOD LEARNING MODELS BASED ON}

the concept of kindness but also the concept of patterns and the others, in order they know a lot about what will be around them.

b. The Values of Religious and Moral

Teaching religious and moral values becomes the main aspect of the character development of the early childhood in Madrasah Qudsiyyah Kudus. To make it happen the Institution creates activities and target indicators of achievement that contains many elements of religious and moral values. These values take precedence, since the strengthening of religious and moral values will be the authorized of the children's religiosity development.

The religious indicator that is developed in the learning process at Madrasah Qudsiyyah is manifested by practicing simple movement of worship, and praying for the daily activities as accustomed. The indicator of the religious development is the Institution's facility to strengthen the children's character, especially in terms of realizing the value of Pinter Ngaji from Gusjigang.

The indicators in the values of faith and moral are taught by various methods, but as the most aspect of educational religious character, these indicators are more taught through the methods of habituation, speech and the concept identification is introduced by the teachers of Madrasah Qudsiyyah, since basically all the teachers of Madrasah Qudsiyyah have a good religious basic.

\section{Aspect of Socialization and Interaction (Nilai Pinter Dagang)}

The development aspect of socialization and interaction in the learning process at Madrasah Qudsiyyah, aligned with the two scopes of early childhood development, those are:

a. Physical

The physical development of learning in Madrasah Qudsiyyah is oriented to provide reinforcement of mobility and acceptability of the children to be individual who is smart in trading 'Pinter Dagang'. The value of Pinter Dagang for the early childhood is defined as the preparation to be having expertise and strength that they become an Intellectual Merchant.

The scope of physical development in Madrasah Qudsiyyah is divided into three parts; those are gross motor, fine motor and physical health. The scope of gross motor physical development schedules the activities that involve the whole body. The indicators of these activities are more intended to train the children's muscles. The activities in this aspect for examples, gymnastic fantasy, capturing objects, crawling, 
walking and running with variations, while physical activities of fine motor is more on the children's creativity development. Its activities are in the physical scope but lighter by promoting carefulness. For examples, writing the Hijaiyyah letters using stationery, arranging the shapes from the pieces of simple geometry and playing music using simple tools.

The aspect of physical health is more on the recognition of the health body for examples weighing, measuring height, as well as health care such as medical checkup. All the activities within the scope of physical development are basically not only implemented in the classroom learning activities, but also carried out through habituations or routines. The medical checkup of children is the example of routine monthly activity that is guided directly by the nurses of the Sub-District Public Health Centre 'Puskesmas' in Kudus, while eating nutritious food on the physical health aspect is carried out through daily habituation.

b. Social Emotional

The scope of social emotional development in Madrasah Qudsiyyah is directed to train the children to develop their personality to be able to interact with the environment harmoniously. In this context, they are trained to be brave, industrious, polite, autonomous, affective, and other construction of emotional character toward maturation. The developed activity indicators are more on the development of self-sufficient and cooperation.

The emotional social development is basically oriented to support the strengthening the value of 'Pinter Dagang'. Because the values of brave, industrious, polite, autonomous, and affective are the basic modal for the children to become good citizens and ready to socialize and interact in the society. The proficiency in the interaction is also one of the modals for the people who want to be a reliable merchant.

The development of self-sufficient for example capable to do the task by themselves, select objects for playing, eating, and playing according to the types of games chosen. While the social activities for example cooperate with friends in a group when doing activities and taking decisions when playing with peers (for instance, deciding who the first to play)

In general, some of the indicators within this scope consist of the activities that need a gradual habituation and training with a particular process without forgetting the teacher's assistances. The teacher acted as the supervisor who gives theoretical 
briefing to be practiced gradually by the children. The given guidances and the implementation of the activities for various age levels are different, also with the level of the teacher's involvement in guiding.

From the annual programs that are presented above, constructing the development design of the learners in accordance with Gusjigang substances, what is actually expected of such design is harmonize all children development with the values of Gusjigang. From there, there is a systemic pattern created by the manager about the internalization of Gusjigang in learning, by interpreting it as the basis of the child development.

This effort is very strategic, since in the term of constructing the comprehension of local wisdom as a basis of life, or in this case is learning, a selective attention to oneself is needed. The selective attention is a process in which a person screens the stimuli that are appropriate or touching. Therefore, our capacity of sensation and perceptual system is limited, so we have to learn how to limit the amount of information that received and processed.

With the position that the early age children still has limitations in terms of choosing what suit on them, hence the efforts of the adults around them are needed (in this case is the teacher), to make a structured pattern in order that children comprehend the values of Gusjigang as a local wisdom that is integral with the classroom learning. Eventually, the children will be able to internalize these values in the development of their character. In other words, once a child learns the concept of Gusjigang, then he will be motivated to apply these values in his life.

In the context of the annual programs, the most concerned by the management of Madrasah is the attempt of children's potentials grouping with the basis of this local wisdom does not lock the children's choices about the life values to be a single option. Nevertheless, the children with their restrictiveness are still free to choose what kind of life values they want. Therefore, in the effort to inheritance the local wisdom as a base of childrens' character development, this grouping of children development basis in learning is quite employed as a reference in case of arranging the best material which is useful for the children development. Whatever the way the children want to process, a teacher have to guide them carefully and affectionately.

As for translating the learning design takes various themes of learning to systemize the implementation of learning in the classroom. The theme of learning for 
the early age children in Madrasah Qudsiyyah is divided into a number of themes, there are:

a. My Islam, this theme can be translated into the various shapes of the weekly activities design that the orientation is to introduce the children to know about Islam and teach them to be good Muslim.

b. My Worship, this theme can be translated into the learning in the forms of worship practices, rote of prayers, helping each others, and other aspects of worship that can give the knowledge about the meaning of worship to children.

c. My Moral, this theme will be elaborated through examples of good morals, how to interact courteously and so on.

d. My Neighborhood, this theme is usually elaborated in the learning in the forms of the children's comprehension, task, and how to preserve the environment.

e. My Letters, It is the theme that gives definition about the Hijaiyyah and the Alphabets for the children. The objectives are to introduce the differences between them and teach to practice.

The division above is aimed to divide the children learning stages at a particular development. The first that has been taught is the aspect of My Moral in which each activity is intended for self-development, the assessment also focused on how the children build their personality. Then it continues gradually to the theme of My Neighborhood, which is the development activity to introduce the natural environment.

The themes that are presented for the early childhood learning in Madrasah Qudsiyyah is directed to internalize Gusjigang in the learning, because the themes of My Moral and My Neighborhood, help the children to do good practice as the value of 'Bagus Lakune'. While the theme of My Islamic, My Worship, and My Alphabet help them to be good in reading Al-Quran as the value of 'Pinter Ngaji'. All of the themes will also be the basis spirit for the children to become a merchant as the value of 'Pinter Dagang'.

\section{CONCLUSION}

The learning design based on the local wisdom in Madrasah Qudsiyyah is oriented towards the development of the basic aspects of the early childhood development that are harmonized with the values of local wisdom of Gusjigang, so the base of the development is directed to: first, the development aspect of commendable morals which targeting to the orientation value of Bagus Lakune of the students; second, the development aspect of intellectual and religious, targeting to 'Pinter Ngaji' value of the students; and third, the development aspect of socialization 
and interaction, as the interpretation of 'Pinter Dagang' value for the students of Madrasah Qudsiyyah. The teaching of local wisdom values in the learning process is taking more meaning and various habit and model from the teacher and the school environment. The acquiring meaning process usually starts from the learning of memorizing the concept to train the children's brain capability, such as rote the Short Surah in the Qur'an, rote Shalawat Tarbiyah which contains a series of behaviors that have to be carried out in their daily life. Then, followed up with a series of habituation activity, all of which are oriented to construct the children's character based on Gusjigang. 


\section{REFERENCES}

Abdullah, Irwan, dkk (Ed). (2008). Agama dan kearifan lokal dalam tantangan global. Yogyakarta: Sekolah Pascasarjana UGM dan Pustaka Pelajar.

An Nahlawi, Abdurrahman. (1995). Pendidikan Islam di rumah sekolah dan masyarakat. Jakarta: Gema Insani Press.

As'ary, Hasyim. (2002). Wong Kudus: Bersikap sak titahe, bergaya maliter. dalam Suara Merdeka. Juli.

Fakhrudin, Asep Umar. (2010). Sukses menjadi guru TK-PAUD, tips, strategi dan panduan-panduan pengembangan praktis. Yogyakarta: Bening.

Hamruni. (2009). Edutainment dalam pendidikan Islam \& teori-teori pembelajaran quantum. Yogyakarta: Fakultas Tarbiyah UIN Sunan Kalijaga.

Ismail, Andang. (2006). Education games, menjadi cerdas dan ceria dengan permainan edukatif. Yogyakarta: Pilar Media.

Khan, D. Yahya. (2010). Pendidikan karakter berbasis potensi diri. Yogyakarta: Pelangi Publishing.

Koesoema A., Doni. (2007). Pendidikan karakter, strategi mendidik anak. Jakarta: Grasindo, 2007.

Mansur. (2005). Pendidikan anak usia dini. Yogyakarta: Pustaka Pelajar.

Masrukhi. (2008). Desain pendidikan karakter melalui pembelajaran PKN di sekolah dasar se Kota Semarang. Semarang: Disertasi PPS UNNES.

Suyanto, Slamet. (2005). Dasar-dasar pendidikan anak usia dini. Yogyakarta: Hikayat Publishing. 